\title{
"Gain without pain: an international case for a tradable green certificates system to foster renewable energy development in Ukraine"
}

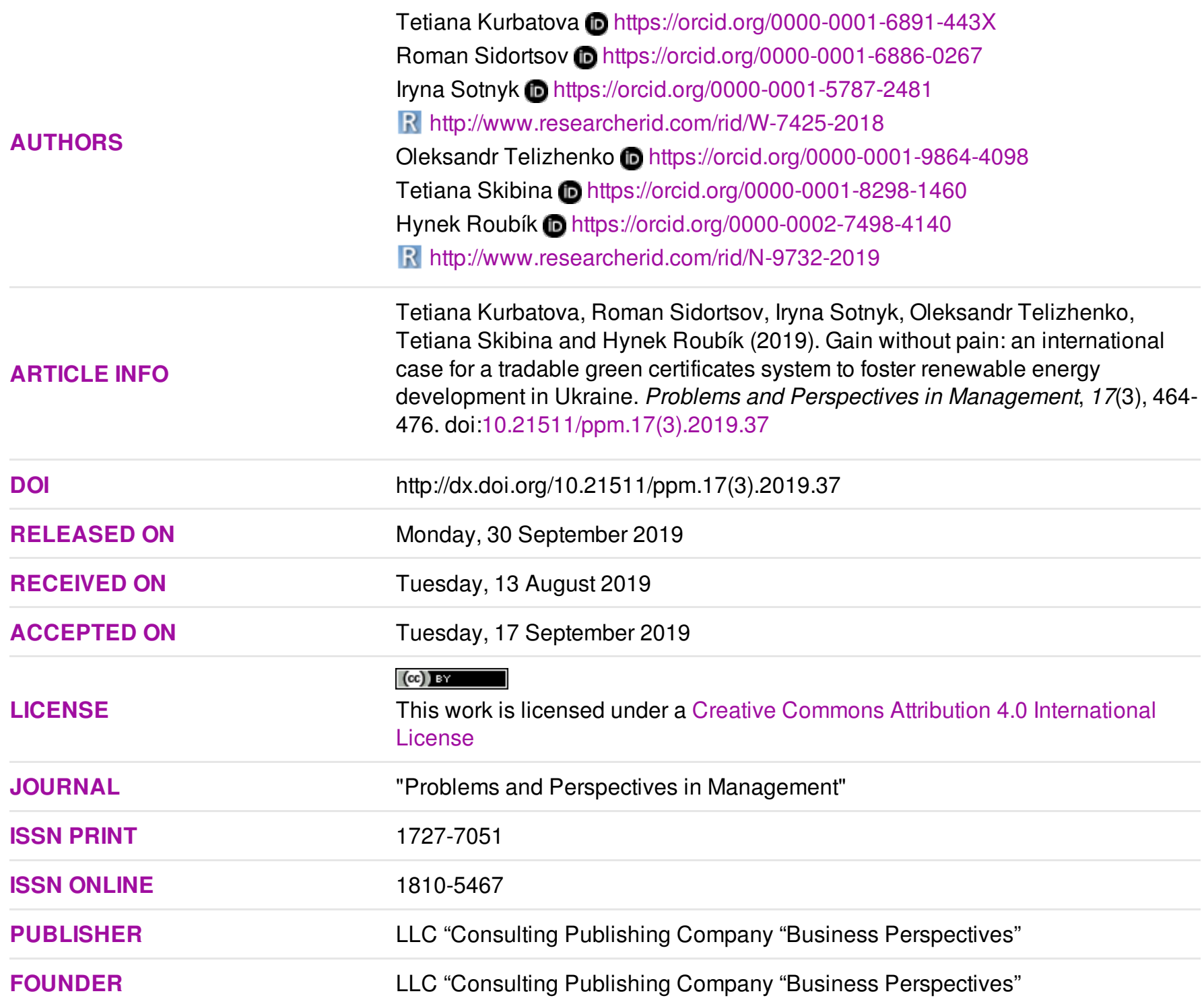

NUMBER OF REFERENCES

38
NUMBER OF FIGURES

1

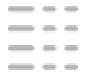

NUMBER OF TABLES

3

(C) The author(s) 2021. This publication is an open access article. 


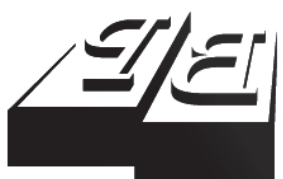

BUSINESS PERSPECTIVES

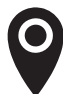

LLC "CPC "Business Perspectives"

Hryhorii Skovoroda lane, 10,

Sumy, 40022, Ukraine

www.businessperspectives.org

Received on: $13^{\text {th }}$ of August, 2019 Accepted on: $17^{\text {th }}$ of September, 2019

(C) Tetiana Kurbatova, Roman Sidortsov, Iryna Sotnyk, Oleksandr Telizhenko, Tetiana Skibina, Roubik Hynek, 2019

Tetiana Kurbatova, Ph.D. in Economics, Senior Lecturer, International Economic Relations Department, Sumy State University, Ukraine.

Roman Sidortsov, Ph.D. in Polar Studies/Geography (cantab), LL.M in Environmental Law, JD, Assistant Professor of Energy Policy, Department of Social Sciences, Michigan Technological University, The United States of America.

Iryna Sotnyk, Doctor of Economics, Professor of the Department of Economics, Entrepreneurship and Business Administration, Sumy State University, Ukraine.

Oleksandr Telizhenko, Doctor of Economics, Head of the Management Department, Sumy State University, Ukraine.

Tetiana Skibina, Ph.D. in Economics, Associate Professor, Finance and Credit Department, Kherson Economy and Law Institute, Ukraine.

Roubik Hynek, Ing., Ph.D. in Sustainable Rural Development, Group Leader of Biogas Research Team at the Department of Sustainable Technologies, Faculty of Tropical AgriSciences, Czech University of Life Sciences Prague, Czech Republic.

\section{(c) (i)}

This is an Open Access article, distributed under the terms of the Creative Commons Attribution 4.0 International license, which permits unrestricted re-use, distribution, and reproduction in any medium, provided the original work is properly cited.
Tetiana Kurbatova (Ukraine), Roman Sidortsov (The United States of America), Iryna Sotnyk (Ukraine), Oleksandr Telizhenko (Ukraine), Tetiana Skibina (Ukraine), Roubik Hynek (Czech Republic)

\section{GAIN WITHOUT PAIN:} AN INTERNATIONAL CASE FOR A TRADABLE GREEN CERTIFICATES SYSTEM

\section{TO FOSTER RENEWABLE ENERGY DEVELOPMENT IN UKRAINE}

\begin{abstract}
This paper elaborates on the theoretical and methodological fundamentals of a tradable green certificates system to foster renewable energy development in Ukraine. It proposes a management mechanism premised on the classical market model of tradable green certificates aiming at increasing the share of electricity from renewable energy sources in the country's energy mix. Organizational stages of the mechanism formation at the national level and a methodological approach to assess green electricity generation cost are developed. The modeling has shown that the annual increase in the cap for green electricity consumption by $1 \%$ will raise the electricity tariff by $3 \%$, which is not a significant financial burden for consumers. The proposed changes in the tradable green certificates system can be an effective management tool to achieve the required amount of electricity from renewable energy sources in the country's total electricity consumption and to foster the development of the Ukrainian renewable energy sector.
\end{abstract}

Keywords

\section{JEL Classification}

renewable energy, management, support mechanism, quota, green certificate, feed-in tariff, Ukraine

\section{INTRODUCTION}

The development of a technologically advanced and internationally competitive economy in Ukraine is contingent on the effective management of the country's energy sector, which at present requires significant improvement. Such improvement can be achieved via increasing energy efficiency and energy independence of the national economy (Sineviciene et al., 2018; Sotnyk, 2016), as well through decreasing the environmental and public health impacts of the energy sector with the help of innovation management focused on renewable energy (RE) deployment (Kubatko \& Kubatko, 2017, 2019).

Currently, despite the gradual reduction of electricity generation cost from renewable energy sources (RES), almost all existing RE technologies in Ukraine are subsidized and cannot develop without governmental support. Therefore, successful development of the RE sector depends on the selection of economic support mechanisms (Papież et al., 2018).

It should be noted that the number of policy mechanisms aimed at promoting electricity generation from RES have been implemented in 
Ukraine since 2009 (Kurbatova, 2018). During 2009-2019, the regulatory framework governing the $\mathrm{RE}$ sector was constantly improved. In particular, a number of legal initiatives were introduced to improve economic incentives, mostly in the part of the feed-in tariff (Law of Ukraine, 1997). However, despite these efforts, the share of RES in the total national electricity consumption remains extremely low reaching only $1.9 \%$ at the end of 2018 (NCSREPU, 2019). The rest of the electricity demand in the country is met with fossil fuel-fired generation, 50\% of which is imported (NCSREPU, 2019). This calls for further government intervention in the energy sector, particularly in optimizing the existing market-based mechanisms, to begin a significant substitution of the conventional electricity generation technologies with RES.

One of the disadvantages of the current set of incentives for RE support in Ukraine is the overreliance on the feed-in tariff (FIT). This policy mechanism aimed at encouraging RE supply is not sufficiently aided by mechanisms that target increasing demand for RE resulting in incoherent market signals. Meanwhile, there are numerous examples globally of demand-centric incentives that work in unison with supply-centric mechanisms such as Renewable Portfolio Standards (RPS) in the United States. An RPS requires an electric utility operating in this U.S. state to supply a set percentage of electricity from renewable sources (National, 2019). These mechanisms have been a major driver behind RE proliferation in individual states despite the resistance from the federal government and some electric utilities (Cavallaro et al., 2017). Drawing upon the international experience of utilizing policy mechanisms aimed at increasing demand for RE, in this study, a theoretical and methodological foundation for a management mechanism for the RE deployment was developed based on a tradable green certificates system (TGCS) and to justify its deployment at the national level to revitalize an RE market in Ukraine.

\section{LITERATURE REVIEW}

A TGCS is an economic mechanism to promote RE development that is based on the establishment of a minimum mandatory requirement for consumption of electricity from RES. A typical TGCS market model is premised on the following two key features. First, it separates physical flow of green electricity from its environmental benefits reflected in green certificates (GCs) cost. It allows using GCs as a tool to achieve relevant goals in various support schemes for RE development. Second, it brings market competition to green electricity generation or consumption in order to form an optimal price for electricity from RES on the basis of demand and supply interaction (Schaeffer et al., 1999).

It should be noted that TGCS-based approaches have been successfully adopted in many developed countries such as the United States, Australia, Japan, Sweden, Denmark, the Netherlands, the United Kingdom and others (REN21, 2017). Adopting a TGCS to a particular national jurisdiction requires a number of adjustments to fit the specific features of a national electricity market, national and sub-national policy goals, and the realities of a national legal and regulatory regime.
A key challenge of implementing a TGCS is to choose the most suitable entities required to generate or consume electricity from RES and to purchase GCs. As the international experience shows, such a responsibility can be imposed on any participant of the electricity market. In Australia, national wholesale electricity markets bear the responsibility whereas in the United Kingdom and Romania it is energy supply companies and in Sweden and Denmark it is end consumers (Nilsson \& Sundqvist, 2007). Other significant differences related to the RES types and to which a TGCS is extended include the GC price formation (Hanne, 2010), the interplay of several national electricity markets with featuring TGCS, and peculiarities of additional support schemes based on the GCs use (NREL, 2014).

A GC is a commercial product, which represents the environmental value of electricity from RES (Holt \& Bird, 2005). A GC is given to a producer of green electricity in exchange for certain amount of the generated electricity. Correspondingly, it proves that a certain amount of renewable electricity was generated and consumed when it was acquired by an economic entity subject to a TGCS requirement. 
The GC price depends on the average market price for conventional electricity and cost of electricity generation from RES. One of a TGCS disadvantages is the complexity of price formation for electricity generated from different types of RES. At any moment, the GC price must meet the price of electricity generated from the most expensive RES within a TGCS to cover the cost for electricity generation from all included RES. An average price for electricity based on all RES covered by a TGCS results in the deployment of the least expensive options because of the incentive to maximize profits. At the same time, because the GC price covers the cost of the most expensive RES, lower-cost RES enjoy windfall profits.

The degree of government intervention in the process of the GC price formation is also of high importance. Currently, there are two main approaches employed by states in this regard. First, it is allowing market self-regulation of price based on the supply and demand for green electricity for as long as the competition remains free of restrains. In this case, a TGCS aims at achieving a set goal (required amount of electricity generated from RES) at any price (Lukosevicius \& Werring, 2011). Under this approach, a TGCS operates with price risks because in case of GCs deficit or surplus on the market, their cost can lead to economically unjustified price. Second, it is a government that determines GC minimum and maximum price caps (Lukosevicius \& Werring, 2011). The price "floor" $\left(P_{\min }\right)$ is used to protect producers from the low price of electricity, which can jeopardize return on the investment. The price ceiling $\left(P_{\max }\right)$ is used to protect end consumers from unreasonably high price of electricity. Under this approach, the GC price is calculated on the basis of green electricity demand and supply interaction and can vary within $\left[P_{\min } \div P_{\max }\right]$ (Imbrescu \& Codruta, 2013).

If economic entities, which are obligated to purchase GC, are not able to fulfill the requirement completely, they must pay a fine for every unpurchased GC established by the government, usually in the amount which exceeds the set GC price. Generally, GCs trade occurs at a specialized market (power exchange) requiring creation of a separate market (Abolhosseini \& Heshmati, 2014).

\section{LAYING A FOUNDATION FOR A TGCS IN UKRAINE}

The first price formation approach described above requires a developed RE market. Because such market is still being developed in Ukraine and the share of electricity generated from RES remains low, the first approach appears to be unsuitable. However, it is reasonable to form a modified TGCS generally premised on the second approach and featuring both ordinary GCs and the credit GCs. At present, this policy mechanism is likely to create a reliable base and optimal conditions for dynamic development of the Ukrainian RE sector. As a TGCS develops and the national RE sector gains prominence, a TGCS can begin moving away from direct government intervention towards classic market.

The proposed TGCS is a mechanism to stimulate generation and consumption of electricity from RES premised on the requirement (quota) to purchase a set amount of green electricity that is imposed on the Ukrainian energy supply companies. The requirement is set proportionally to the amount of electricity sold to end consumers by each supply company. The fulfillment of the imposed obligation is confirmed by the fact of possession of the required number of GCs, which have been purchased according to the terms of a TGCS.

Under the proposed TGCS, green electricity is sold at the national wholesale electricity market at the average market price. This price includes both the price for electricity generated based on all conventional energy generation technologies presented on the Ukrainian electricity market (fossil fuel-fired conventional power and combined heat and power plants, nuclear power plants, and large hydropower plants) and the price of GCs, which will the help to offset extra RES-generated cost. Revenue from these two sources will not also help achieve reasonable profit by owners of RE plants thereby creating a lasting incentive for RES growth.

Some countries set a GC price based on average cost of all participating RE technologies (Devenyi \& Mladenova, 2012). However, the current article proposes to follow another setting a GC 
price for each type of participating RE technology (Imbrescu \& Codruta, 2013). Although this approach complicates the GC price calculation, it can provide fair pricing for electricity and formation of the more competitive and diverse RES mix. It is recommended that the GC market in Ukraine should be a separate segment of the national wholesale electricity market, where GCs transactions take place based on agreements between producers of green electricity and energy supply companies.

For an effective introduction of a TGCS in Ukraine, it is necessary to do so via a number of organizational stages. Each of them is considered in more detail below:

1. Creation of the Department of RE Development (DRED) within the National Commission for State Regulation of Energy and Public Utilities (NCSREPU) and giving it the authority to monitor and control a TGCS.

2. Accreditation of RE generating capacities. Accreditation is aimed at identification and evaluation of RE plants eligible to receive GCs. It is proposed to include solar, wind, biomass (solid biomass, landfill biogas, and agriculture biogas) and small hydro (with total installed capacity up to $10 \mathrm{MW}$ ) facilities.

3. Setting the annual requirement (quota) for green electricity consumption. DRED of NCSREPU calculates predictable indicators of green electricity share in the total electricity mix for the reporting year based on the established long-term goals to increase the RES share in the total electricity consumption and tracks the dynamics of RE development indicators. This serves as the basis for the requirement (quota) for renewable electricity consumption for each year.

4. Identification of all economic entities required to consume green electricity and purchase GCs. All electricity consumers receive a certain share of green electricity, which is reflected in their electricity bills. All energy supply companies that purchase wholesale electricity are required to buy GCs.
5. Formation of a single register and an accounting system for a TGCS. DRED forms and keeps a single electronic register that keeps track of all RE generation facilities and their owners and operators, as well as all economic entities obliged to purchase GCs. These accounts are necessary not only to facilitate GCs circulation among the economic entities involved in a TGCS but also to report to the NCSREPU regarding compliance with TGCS requirements.

6. Collecting information about the amount of electricity generated from RES. On a monthly basis, energy supply companies provide the NCSREPU with the information about the electricity from RES and supplied to consumers connected via the grid within their service area (license authority).

7. Issuance of GCs. The NCSREPU facilitates GCs issuance in the electronic form. GCs validity period is one year.

8. GC transfers. Based on the energy supply companies' data in the beginning of each month, the NCSREPU transfers the appropriate number of GCs to the generating companies for the green electricity generated and supplied to the grid in the previous month.

9. GC purchase requirement. Energy supply companies, which are required to purchase renewable electricity, must purchase the corresponding number of GCs to satisfy the requirement for the set year.

10. Purchase and sale of GCs. As mentioned above, purchase and sale of GCs must be carried out under contracts between eligible electricity producers and participating energy supply companies at the centralized GC market.

11. Fulfillment of obligations to purchase GCs. End consumers have to pay for electricity from RES reflected in their electricity bill on a monthly basis. Energy supply companies must meet their GC purchase requirements by the end of the reporting year. Until the end of the first quarter of each reporting year, the NCSREPU relies on the estimates that 
are based on historic GC sales and renewable electricity supply to determine compliance with the TGCS requirements. Energy supply companies that are required to purchase GCs must transfer the appropriate number of GCs to a special account at the NCSREPU for their further repayment. If renewable electricity generated for the reporting year exceeds the required amount, a participating RE facility owner has the right to apply unrealized GCs in the next reporting period.

12. Penalties for non-compliance. Energy supply companies that are required to purchase GCs and have not fulfilled the requirement during the reporting year must pay a fine for every unpurchased certificate.

According to the current Ukrainian legislation, the FIT-based support scheme for RE development will remain until January 1, 2030. Because it is an established and working mechanism that involves a number of completed and forthcoming projects, it is not practicable to treat the proposed TGCS as its replacement. Rather, the current study sees the proposed TGCS complementing and aiding the existing scheme to accelerate development of new RE capacities.

FIT with a TGCS, an additional obligation (to a TGCS requirement) is proposed, under which power supply companies will purchase the electricity sold by FIT-supported entities for subsequent resale to first-class-voltage consumers, who are the largest electricity users and enjoy electricity tariffs (rates) that are 20\% lower than for the second-class-voltage consumers (NCSREPU, 1998). According to the NCSREPU resolution (NCSREPU, 1998), the first-class-voltage consumers include entities that:

- receive electricity from an energy supplier at the electricity sale point with $27.5 \mathrm{~kW}$ voltage level and higher;

- are connected to the power plants buses (except for hydropower plants that suffer from intermittent output) and to the buses of power plants substations with $220 \mathrm{~kW}$ and higher voltage regardless of voltage degree at the electricity sale point;
- are industrial enterprises with an average monthly electricity consumption of 150 million $\mathrm{kWh}$ for industrial applications regardless of voltage levels at the electricity sale point.

First-class-voltage consumers include predominately industrial customers that are the largest emitters of the greenhouse gases, the polluterpays principle justifies the extra obligation. It is a viable incentive to reduce electricity consumption through improving energy efficiency and introducing demand side management, as well as investing in RE projects in order to obtain GCs to meet obligations under a TGCS. A significant immediate financial burden on industrial consumers is not anticipated because the share of renewable electricity generated as part of the FIT scheme in Ukraine today is low. In addition, in 2016-2019, conventional electricity tariffs (rates) grew more than twice and they are planned to grow gradually in the future (NCSREPU, 2019). Thus, the extra obligation will not only help achieve environmental benefit but also provide a strong market signal for industrial facilities to wean off ever increasingly expensive fossil fuels in favor of ever increasingly cheap RE (Sovacool et al., 2014). Figure 1 summarizes a TGCS foundation outlined above.

As mentioned above, the proposed TGCS is based on circulation of both ordinary GCs and credit GCs. The main purpose behind GCs is to obtain extra financial resources by investors to develop new RE facilities. Given the infancy of the RE market in Ukraine, it is likely that the amount of electricity generated from RES by operating the existing RE plants will be insufficient to meet even a modest RE goal. Credit GCs provide a pay-it-forward solution for the Ukrainian RE market infancy, albeit a non-altruistic one.

Credit GCs take a form of securities with one-year maturing period. When they are sold and purchased at the GC market, end consumers effectively pay for non-generated electricity from RES. As a result, investors get an interest-free or a low interest rate loan to partially offset generally high capital cost of RE projects.

DRED, the proposed agency charged with regulating and oversight of the RE sector, announces a competitive tender of RE projects, the winners 


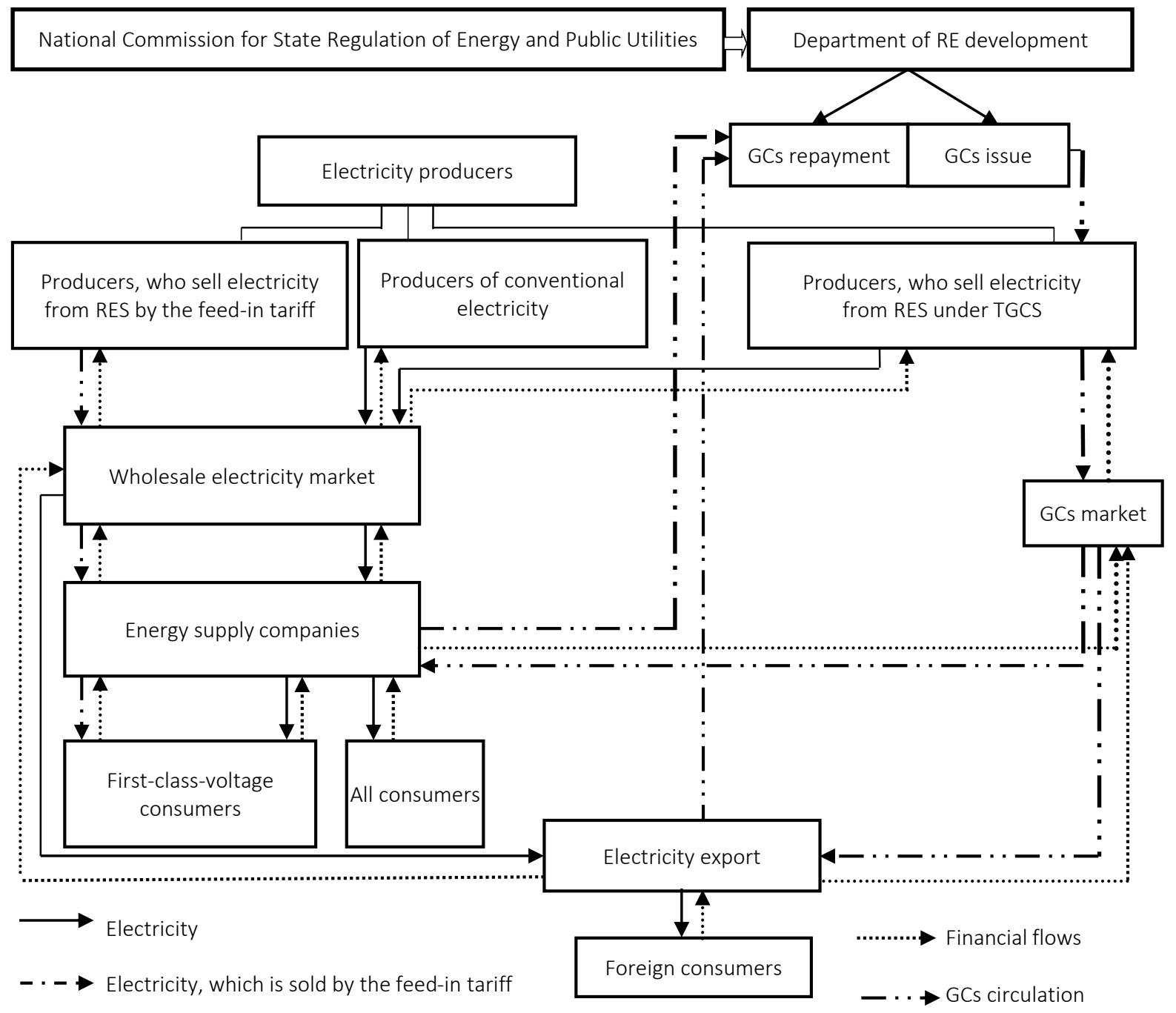

Figure 1. The wholesale and retail electricity markets operating scheme with combination of electricity sold by the feed-in tariff and a TGCS

of which can gain access to credit GCs financing. The selection process should take into account the current total installed RE capacity, price, preferred types of RES (on reliability and resilience grounds), spatial allocation of RE facilities and other factors. An investor enters into an agreement with DRED about supporting its RE project via issuing a certain amount of the credit GCs. The agency issues credit GCs according to the average annual projected amount of electricity to be generated by this RE facility. This opens the door for power supply entities, which have obligations under a TGCS to meet them with the issued credit GCs. The transaction occurs under the same rules as in the case of ordinary GCs. The funds received from the credit GCs' sale are transferred to the investor, which uses them to finance the new RE plant. After putting the RE plant into operation, its owner also issued ordinary GCs in proportion of the generated renewable electricity. Unlike with credit GC, these certificates must be repaid immediately bypassing the GC market until their quantity is equal to the amount of the credit GCs sold with the aim to finance the construction of the RE plant.

It should be noted that the replacement of the credit GCs by the ordinary ones is carried out based on the amount of electricity generated from RES (according to their quantity) and is not based on the current GCs price. In other words, the government gives an investor the amount of green electricity in $\mathrm{MWh}$ in the form of funds received from selling a certain quantity of the credit GCs, so that after 
putting the RE plant into operation, the investor can reimburse the government for said amount of electricity expressed in the quantity of the ordinary GCs. Hence, credit GCs can be used as part of an RE projects financing package, and are not intended to covering all investment cost required for RE facility construction.

\section{METHODS}

In addition to laying a foundation of the proposed TGSC, it is important to form methodological approaches to assessment of electricity generation cost from different types of RES. Electricity generation cost from RES can be calculated on the basis of levelized cost of electricity (LCOE) method. Today LCOE is widely used for comparative analysis of electricity generation cost for different energy technologies by a number of organizations such as the International Energy Agency (IEA, 2010), the International Atomic Energy Agency (IAEA, 2015) and the International Renewable Energy Agency (IRENA, 2012). Germany, the Netherlands, Great Britain, and Spain use LCOE as a base to calculate national FITs for RE plants (Visser \& Held, 2014). In order to get more precise results, Khatib (2010) recommends calculating LCOE for every country, since LCOE depends on specific conditions of RE projects development, such as financing costs, resource availability, and siting and permitting requirements that vary greatly from jurisdiction to jurisdiction.

In order to determine electricity generation cost from RES under the proposed TGCS, it is necessary to take into account the following indicators: investment, operation and maintenance cost, fuel cost, decommissioning cost, amount of generated electricity and discount rate.

According to the noted above, LCOE can be calculated as follows:

$$
L C O E_{i}=\frac{\sum_{t=0}^{n}\left(I_{i t}+Q \in M_{i t}+F_{i t}+D_{i t}\right) \cdot(1+r)^{-t}}{\sum_{t=0}^{m}\left(E_{i t} \cdot(1+r)^{-t}\right)}, \text { (1) }
$$

where $E_{i t}$ - amount of electricity generated from $i$ type of RES in year $t$, MWh; $L C O E_{i}$ - price for electricity generated from $i$ type of RES during the RE plant's lifetime EUR/MWh; $I_{i t}$ - investment cost for the RE plant based on $i$ type of RES in year $t$, EUR/MWh; $Q \in M_{i t}$ - operation and maintenance cost for the RE plant based on $i$ type of RES in year $t$, EUR/MWh; $F_{i t}$ - fuel cost for the RE plant based on $i$ type of RES in year $t$, EUR/MWh; $D_{i t}$ - decommissioning cost for the RE plant based on $i$ type of RES in year $t$, EUR/ MWh; $t$ - year of the project implementation; $r$ discount rate; and $n$ - duration of the RE plant's lifetime, years.

Given the fact that within a TGCS, the price of electricity from RES is divided into two constituents, namely price of conventional electricity and price of the GCs, it can be calculated according to the following formula:

$$
P_{R E i}=L C O E_{i}=P_{C E}+P_{G C i},
$$

where $P_{R E i}$ - price of electricity generated from $i$ type of RES, EUR/MWh; $P_{C E}$ - annual predictable average weighted market price of conventional electricity, EUR/MWh; $P_{G C i}$ - price of GCs for electricity generated from $i$ type of RES, EUR/ MWh.

It is reasonable to calculate the annual average weighted market price of conventional electricity on the basis of the projected wholesale price at the Ukrainian wholesale electricity market. It should be noted that the amount of electricity generation from some RES types directly depends on weather conditions. That is why both deficit and surplus of electricity from RES can appear in the proper months of the year. The set average weighted price of conventional electricity allows minimizing fluctuations of the GCs price. It gives an opportunity for energy supply companies to cover the requirement (quota) during the reporting year under the same price terms.

Having calculated the annual predictable average weighted market price for conventional electricity, the GC price can be determined according to the following formula:

$$
P_{G C i}=P_{R E i}-P_{C E} .
$$

In order to simplify a GCs issuance, it is proposed to set a single GC price. Since various RE tech- 
nologies have different prime cost of electricity, it is reasonable to take GC cost for the cheapest RE technology as a single certificate price. The price for electricity based on various RE technologies can be regulated by issuing a varied number of GCs to producers for $1 \mathrm{MWh}$ generated from different RES. It is reasonable to set the quantity of the GCs issued to producers that employ different RE technologies for $1 \mathrm{MWh}$ of the cheapest technology presented on the RE market:

$$
Q_{G G i}=\frac{P_{G C i}}{P_{G C L}},
$$

where $Q_{G G i}$ - the quantity of the GCs issued for producers according to the price for $1 \mathrm{MWh}$ of electricity generated from $i$ type of RES, units/ MWh; $P_{G C L}-$ GCs price for electricity generated on the basis of the cheapest RE technology presented on the RE market, EUR/MWh.

Thus, from producer's position, the price of 1 MWh of electricity generated from $i$ type of RES $\left(P_{P R O D i}\right)$ can be calculated as follows:

$$
P_{P R O D i}=P_{R E i}=P_{C E}+P_{G C L} \cdot Q_{G G i} .
$$

In order to keep a single price for electricity for end consumers in Ukraine, calculating the GCs quantity, which must be purchased by energy supply companies, should be based on the projected average weighted quantity of the GCs issued to producers according to the projected annual amount of renewable electricity.

The annual projected average weighted quantity of the GCs for $1 \mathrm{MWh}\left(Q_{W A}\right)$, which will be in circulation in the reporting year according to the projected annual amount of electricity generated from RES by the operating RE facilities, is calculated as follows:

$$
Q_{W A 1}=\frac{\sum_{i=1}^{k} Q E_{y i} \cdot Q_{G G i}}{\sum_{i=1}^{k} Q E_{y i}},
$$

where $Q_{W A 1}$ - annual predictable average weighted quantity of the GCs, which will have been in circulation in the reporting year, calculated based on the projection of electricity generated from op- erating RE plants, units/MWh; $k$ - number of RE technologies presented on the electricity market in the reporting year; $Q E_{y i}$ - predictable amount of electricity generated by operating RE plants in the reporting year, $\mathrm{MWh} /$ year; $Q_{G G i}$ - number of certificates issued to producers according to the price of $1 \mathrm{MWh}$ of electricity generated from $i$ type of RES, units/MWh.

If the NCSREPU decides to issue credit GCs, the annual average weighted quantity of the GCs for 1 MWh $\left(Q_{W A 2}\right)$, which will be in circulation in the reporting year, can be calculated as follows:

$$
Q_{W A 2}=\frac{\sum_{i=1}^{k}\left(Q E_{y i}+Q E_{K G C y i}\right) \cdot Q_{G C i}}{\sum_{i=1}^{k}\left(Q E_{y i}+Q E_{K G C y i}\right)},
$$

where $Q_{W A 2}$ - annual predictable average weighted quantity of the GCs, which will be in circulation in the reporting year, calculated on the basis of electricity amount generated by the operating $\mathrm{RE}$ plants and accounting for the issued credit GCs, units/MWh; $Q E_{K G C y i}$ - amount of electricity from RES (which is necessary to fulfill the annual requirement) planned to cover by the credit GCs issued in the reporting year, MWh.

In order to calculate the number of the GCs purchased by the participating energy supply companies that are obligated to purchase them according to the requirement (quota) $\left(N_{G C}\right)$, the following formula is proposed:

$$
N_{G C}=Q E \cdot \alpha \cdot Q_{W A 1(2)},
$$

where $Q E$ - amount of electricity purchased by the energy supply companies at the national wholesale electricity market, MWh/year; $\alpha$ - requirement for renewable electricity consumption for the reporting year, part of one; $Q_{W A 1(2)}$ - annual average weighted number of GCs that would have been in circulation in the reporting year, depending on the selected variant ((1) to use or (2) not to use the credit GCs), units/MWh.

Sum, which must be paid by energy supply companies for certificates purchased according to the annual requirement (quota) $\left(P_{E S C}\right)$ is calculated as follows: 


$$
P_{E S C}=N_{G C} \cdot P_{G C L}
$$

It should be noted that unfulfilled obligations to purchase GCs according to the annual requirement (quota) for renewable electricity consumption in a TGCS result in a fine. The fine for the unpurchased GCs is paid as an extra percentage of the certificate cost for the electricity generated based on the cheapest RE technology presented on the RE market. It can be calculated as follows:

$$
F=\left(N_{G C}-N_{G C F}\right) \cdot P_{G C L} \cdot k_{f},
$$

where $F$ - fine for unfulfilled obligation within the framework of a TGCS, EUR, $N_{G C F}$ - number of purchased GCs in the reporting year, units; $k_{f}$ - fine coefficient.

In order to count the price of $1 \mathrm{MWh}$ of electricity for end consumers $\left(P_{\text {CONS }}\right)$, the following formula is proposed:

$$
\begin{aligned}
& P_{C O N S}=(1-\alpha) \cdot P_{C E r}+ \\
& +\alpha \cdot\left(P_{C E r}+P_{G C L} \cdot Q_{W A 1(2)}\right) .
\end{aligned}
$$

The methodological approaches proposed above allow for calculating the price for electricity from by both owners of RE facilities and end consumers.

\section{RESULTS AND DISCUSSION}

In order to calculate LCOE, the article used data regarding RE projects, which were implemented in Ukraine during 2015-2017. These data were provided by the Ukrainian Renewable Energy Association (Baker Tilly, 2015), the Ukrainian Wind Energy Association (UWEA, 2016) and the engineering company "Rentechno" (Engineering, 2016). In addition, the recommendations of the Ukraine Sustainable Energy Lending Facility (USELF) (USELF, 2014) and the International Energy Agency (IEA, 2015) were used. The discount rate was calculated based on the average weighted cost of capital and the risk premium according to Moody's and Standard \& Poor's for 2018 (Damodaran, 2018) amounting to $12 \%$ in euro (EUR). It is worth noting that the high discount rate is due to the high risk of doing business in
Ukraine that is largely due to the armed conflict in the east of the country. The official exchange rate of the National Bank of Ukraine as of February, 1 2019 (31.8 UAH for 1 EUR) was used for currency conversion (NBU, 2019). $L C O E_{i}$ for electricity generated on the basis of various $R E$ technologies was calculated according to formula (1) and pre-

\begin{tabular}{|c|c|c|}
\hline $\begin{array}{l}\text { Types of renewable } \\
\text { energy plants }\end{array}$ & $\begin{array}{c}\text { Electricity } \\
\text { generation } \\
\text { cost } L C O E_{i}=P_{R e i} \\
(E U R / M W h)\end{array}$ & $\begin{array}{l}\text { GC price, } P_{\text {CGi' }} \\
\text { (EUR/MWh) }\end{array}$ \\
\hline Solar power plants & 188.52 & 212.81 \\
\hline Wind power plants & 79.44 & 76.46 \\
\hline $\begin{array}{l}\text { Small hydropower } \\
\text { plants }\end{array}$ & 77.01 & 73.42 \\
\hline $\begin{array}{l}\text { Bioenergy plants } \\
\text { (landfill biogas) }\end{array}$ & 48.42 & 37.69 \\
\hline $\begin{array}{l}\text { Bioenergy plants (solid } \\
\text { biomass) }\end{array}$ & 85.19 & 83.65 \\
\hline $\begin{array}{l}\text { Bioenergy plants } \\
\text { (agricultural biogas) }\end{array}$ & 49.94 & 39.58 \\
\hline
\end{tabular}
sented in Table 1.

Table 1. The LCOE and the GC price for different types of RE plants in Ukraine

The price of conventional electricity $\left(P_{C E}\right)$ was calculated based on the analysis of electricity sale at the Ukrainian wholesale electricity market from September 1, 2018 until February 1, 2019. The average weighted wholesale price for purchasing conventional electricity during this period was 22.84 EUR/MWh (WEMU, 2019).

According to formula (3), the calculated price of the GC $\left(P_{G C i}\right)$ for electricity generated on the basis of different RES types is presented in Table 1 as well. Table 1 shows that the various RE technologies have different cost. In order to simplify price fluctuations during the issuance and circulation of GCs, it is proposed to set a single GC price. It is reasonable to use the GC price for the cheapest RE technology that is bioenergy plants (landfill biogas) at 37,69 EUR/MWh.

Regulation of the electricity cost based on various RES types can be performed by issuing different quantity of GCs to producers per unit of electricity generated. Formulas (4) and (5) were used to calculate the required number of GCs and the renewable electricity price per MWh. This calculation would have been performed by electricity producers. The results are depicted in Table 2. 
Table 2. Number of GCs that producers of electricity from different types of RES would have obtained per $1 \mathrm{MWh}$ and cost of electricity generation from RES

\begin{tabular}{|c|c|c|}
\hline Types of RE plants & $\begin{array}{l}\text { Number of GCs that producers of } \\
\text { electricity from RES would have } \\
\text { obtained, } Q_{G C i} \text { (units/MWh) }\end{array}$ & $\begin{array}{l}\text { Cost of electricity generation from RES } \\
\text { from the producers' side, } P_{P R O D i}=P_{R e i} \\
\text { (EUR/MWh) }\end{array}$ \\
\hline Solar power plants & 5.65 & 235.65 \\
\hline Wind power plants & 2.03 & 99.30 \\
\hline Small hydropower plants & 1.95 & 96.26 \\
\hline Bioenergy plants (landfill biogas) & 1.00 & 60.53 \\
\hline Bioenergy plants (solid biomass) & 2.23 & 106.49 \\
\hline Bioenergy plants (agricultural biogas) & 1.05 & 62.42 \\
\hline
\end{tabular}

To test the proposed methodology, the following assumptions were made and results achieved:

1. The projected consumption of electricity based on the 2018 data is 128.39 TWh (SSSU, 2019).

2. The renewable electricity consumption requirement (quota) is $2 \%$ or $2.57 \mathrm{TWh}$.

3. The projected amount of electricity generated by the operating RE plants covers only $75 \%$ of the annual RE requirement. In order to meet the rest $25 \%$, the NCSREPU issues credit GCs.

4. The electricity amount generated from various RES is assumed according to the RES mix in Ukraine as of 2018: solar power plants at $24.2 \%$, wind power plants at $58.3 \%$, small hydropower plants at $12.5 \%$, bioenergy plants (solid biomass) at 3\%, bioenergy plants (biogas from agricultural waste) at $1 \%$, and bioenergy plants (landfill biogas) at $1 \%$ (NCSREPU, 2019).

5. The structure of the renewable electricity mix to be supported by credit GCs is set according to the state priorities for RE development with solar power plants at $15.3 \%$, wind power plants at $40.4 \%$, small hydropower plants at $25.3 \%$, bioenergy plants (solid biomass) at $8 \%$, bioenergy plants (biogas from agricultural waste) at $4 \%$, and bioenergy plants (landfill biogas) at $7 \%$.

6. The amount of the electricity purchased by the energy supply company, for which calculation is carried out at the national wholesale electricity market in the reporting year, is 106.92 GWh.
7. The energy supply company met $95 \%$ of its obligation to purchase GCs in the reporting year having purchased 5,648 certificates.

8. The fine for the unfulfilled obligation is set at $20 \%$ of the GC cost for the electricity generated on the basis of the cheapest RE technology presented on the electricity market.

9. The end consumer, for whom the calculation is performed, belongs to the category that draws more than $100 \mathrm{kWh}$ per month per consumer and $300 \mathrm{kWh}$ on average per month. As of January 2019, the tariffs (rates) set by NCSREPU are: 0.02 EUR for $1 \mathrm{kWh}$ of electricity (without the value added tax) if the consumption is less than $100 \mathrm{kWh}$ per month and 0.04 EUR for $1 \mathrm{kWh}$ of electricity if the consumption is over $100 \mathrm{kWh}$ per month. Thus, per annum, the consumer pays 20 EUR per $1 \mathrm{MWh}$ for $1.2 \mathrm{MWh}$ and 40 EUR for 1 MWh for the rest 2.4 MWh amounting to 120 EUR (33,33 EUR for 1 MWh) for 3.6 MWh.

Based on the assumptions above, the projected annual amount of electricity generated by operating RE plants, the projected annual amount of electricity generation supported by credit GCs, and the average weighted quantity of the certificates in circulation in the reporting year are calculated according to formula (7) and depicted in Table 3.

The calculation of the total quantity of the certificates, which would have been in circulation in the reporting year, is based on the amount of electricity generated from RES, which is difficult to estimate with certainty. Therefore, the NCSREPU has to use a lower estimate of the projected amount of electricity generated by the operating RE plants, as well as 
Table 3. Projected annual amount of electricity generation by the operating RE plants; projected annual amount of electricity generation supported by credit GCs; and the average weighted number of certificates in circulation in the reporting year

\begin{tabular}{|c|c|c|c|c|}
\hline \multirow{2}{*}{ Types of RE plants } & \multicolumn{2}{|c|}{$\begin{array}{l}\text { Projected annual amount of } \\
\text { electricity generated from RES, MWh }\end{array}$} & \multirow{2}{*}{$\begin{array}{l}\text { Total number of } \\
\text { the certificates in } \\
\text { circulation in the } \\
\text { reporting year, } \\
\text { (units/MWh) }\end{array}$} & \multirow{2}{*}{$\begin{array}{l}\text { Average weighted } \\
\text { number of certificates } \\
\text { in circulation in the } \\
\text { reporting year, } Q_{W A 2} \\
\text { (units/MWh) }\end{array}$} \\
\hline & $\begin{array}{l}\text { By the operating } \\
\text { RE plants, } Q E_{y i}\end{array}$ & $\begin{array}{c}\text { Supported by } \\
\text { credit GCs, } Q E_{K G C y i}\end{array}$ & & \\
\hline Solar power plants & $466,046.02$ & $98,216.82$ & $3,128,995$ & \multirow{7}{*}{2.78} \\
\hline Wind power plants & $1,122,747.23$ & $259,343.76$ & $2,853,354$ & \\
\hline Small hydropower plants & $240,726.25$ & $162,410.82$ & 785,791 & \\
\hline Bioenergy plants (landfill biogas) & $19,258.10$ & $44,935.80$ & 64,194 & \\
\hline Bioenergy plants (solid biomass) & $57,774.30$ & $51,355.20$ & 251,166 & \\
\hline Bioenergy plants (agriculture biogas) & $19,258.10$ & $25,677.60$ & 48,065 & \\
\hline Total & $1,925,810$ & 641,940 & $7,131,566$ & \\
\hline
\end{tabular}

the amount of electricity supported via credit GCs. If the actual generation data varies from the projections, the NCSREPU will balance the deviation through issuing credit GCs at the end of the year.

Assuming that the energy supply company, for which calculation is carried out, purchased $106,920 \mathrm{MWh}$ per year at the wholesale electricity market, the number of GCs necessary to meet obligations to purchase electricity from RES according to the $2 \%$ requirement (quota) is calculated through formula (8) and amounts to 5,945 units. Therefore, the energy supply company has fulfilled
95\% of its GC purchase obligation having bought 5,648 certificates. In addition, applying formula (10), the fine, which is to be paid for the unfulfilled obligation, is 13432,72 EUR.

According to the assumptions above and formula (11), price of $1 \mathrm{MWh}$ for end consumers within a TGCS is $35,43 \mathrm{EUR} / \mathrm{MWh}$. It is higher than the current tariff for the mentioned consumers of electricity by $6 \%$. Thus, a $1 \%$ increase in the quota for consumption of green electricity will lead to the tariff growth by $3 \%$ that will not be a significant financial burden for end electricity consumers.

\section{CONCLUSION}

The proposed TGCS is a new policy mechanism to promote RE development in Ukraine. Implementing a TGCS likely faces a number of challenges, some of which are outlined throughout this article. However, a thoughtful design based on a thorough evaluation of important criteria, such as pricing and competitive environment formation, can result in an effective policy supporting the development of the budding RE sector in Ukraine.

The results show that an introduction of a requirement (quota) for green electricity consumption will result in a 3\% increase in the electricity tariff (rate) for end consumers. This increase is insignificant, especially given more than doubling of electricity prices during the last few years in Ukraine. In addition, to soften the financial burden for end consumers in the short term, the government could support the development of the cheapest RE technologies with the help of credit GCs. In the long term, a significant increase in electricity tariffs (rates) with expansion of the requirement (quota) is not anticipated because of the ever-declining LCOE of RE.

Furthermore, in order to implement the proposed TGSC effectively, deployment of RE facilities must be supplemented by sweeping energy efficiency and demand side management measures. Fluctuations of the renewable electricity share in the total electricity mix depend not only on the amount of electricity generated from RES but also directly on the amount of its consumption in the reporting period. Therefore, taking such measures is important as it increases the overall success of policies aimed at rapid RE development with the help of a TGCS. 


\section{ACKNOWLEDGMENT}

The article contains results of the research supported through the Ministry of Education and Science of Ukraine's research framework "Organizational and economic mechanisms for stimulating renewable energy development in Ukraine" (No. 0117U002254) and "System model of efficiency management and forecasting of electricity use" (No. 0118U003583).

\section{REFERENCES}

1. Abolhosseini, S., \& Heshmati, A. (2014). The main support mechanisms to finance renewable energy development. Retrieved from http://repec.iza.org/ dp8182.pdf

2. Baker Tilly. (2015). Report on the assessment of impact of feed-in tariff change on investment attractiveness of renew able energy projects (13 p.).

3. Cavallaro, C., Pearce, J., \& Sidortsov, R. (2017). Decarbonizing the boardroom? Aligning electric utility executive compensation with climate change incentives. Energy Research and Social Science, 37. https://doi.org/10.1016/j. erss.2017.09.036

4. Damodaran, A. (2018). Country default spreads and risk premiums. Retrieved from http://pages.stern.nyu. edu/ adamodar/New_Home_Page/ datafile/ctryprem.html

5. Devenyi, R., \& Mladenova, I. (2012). International markets for renewable energy certificates. Retrieved from http://sustainround.com/library/sites/ default/files/SRER_Member\%20Briefing_International $\% 20$ Markets $\% 20$ for $\% 20$ Renewable $\% 20$ Energy $\% 20$ Certificates_2012-07-16.pdf

6. Engineering company "Rentehno". (2016). Technical and economic characteristics of solar power plant with a total installed capacity of $1 \mathrm{MW}$ : information letter No. 11/04-2.

7. Hanne, S. (2010). A green certificate market in Norway and its implication for the market participants. Retrieved from https://www.ethz.ch/content/ dam/ethz/special-interest/mtec/cepe/ cepe-dam/documents/education/selected-term-papers/Goldstein.pdf

8. Holt, E., \& Bird, L. (2005). Emerging markets for renewable energy certificates: opportunities and challenges. Retrieved from http://www.nrel.gov/docs/fy05osti/37388.pdf

9. International Atomic Energy Agency. (2015). Climate change and nuclear power. Retrieved from https://www.iaea. org/publications/10928/climate-changeand-nuclear-power-2015
10. International Energy Agency. (2015). Projected costs of generating electricity. Retrieved from https://www.oecd-nea. org/ndd/pubs/2015/7057-proj-costselectricity-2015.pdf

11. International Atomic Energy Agency. (2010). World Energy Outlook. Retrieved from https://www.iea.org

12. Imbrescu, C., \& Codruta, P. (2013). The accounting treatment of green certificates. Lucrări Științifice, 18, 119-126. Retrieved from http://lsma.ro/index. php/lsma/article/view/864

13. International Renewable Energy Agency. (2012). Summary for policy makers: renewable power generation costs. Retrieved from http://www.irena. org/DocumentDownloads/Publications/Renewable Power Generation_Costs.pdf

14. Khatib, H. (2010). The World Energy Congress 2010 - A review. Energy Policy, 39, 2213-2215.

15. Kubatko, O., \& Kubatko, O. (2017). Economic estimations of pollution related cancer and nerves morbidity. International Journal of Ecology \& Development, 32(1), 33-43. Retrieved from http://www.ceser.in/ceserp/index. php/ijed/article/view/4765

16. Kubatko, O., \& Kubatko, O. (2019). Economic estimations of air pollution health nexus. Environment. Development and Sustainability, 21(3), 15071517. https://doi.org/10.1007/s10668018-0252-6

17. Kurbatova, T. (2018). Economic benefits for producers of biogas from cattle manure within energy co-operatives in Ukraine. International Journal of Sustainable Energy Planning and Management, 18, 69-80. https:// doi.org/10.5278/ijsepm.2018.18.5

18. Lukosevicius, V., \& Werring, L. (2011) Building for sustainable energy regulation in Eastern Europe and Central Asia (113 p.). ERRA, Budapest,

19. Moraru, D. (2015). The need for win regulations regarding the harmonization of advantages for the renewable energy sector and the concerns about the environment. Management \&
Marketing, Challenges for the Knowledge Society, 10(1), 61-71. https://doi. org/10.1515/mmcks-2015-0005

20. National Bank of Ukraine. (2019). Official exchange rate of hryvnia against foreign currencies as of February 1, 2019.

21. National Commission for State Regulation of Energy and Public Utilities (1998). Resolution: on the procedure for determining the classes of consumers No. 1052, 3.08.1998. Retrieved from http://search.ligazakon.ua/1_doc2.nsf/ link1/GK014.html

22. National Commission for State Regulation of Energy and Public Utilities (2015). Resolution on the establishment of tariffs for electricity sold to the population No. 220, 26.02.2015. Retrieved from http://www.nerc.gov. ua/?id=14359

23. National Commission for State Regulation of Energy and Public Utilities (2019). Report on the results NCSREPU activity in 2018: decree No. 440, 29.03.2019. Retrieved from http:// www.nerc.gov.ua/data/filearch/Catalog3/Richnyi_zvit_NKREKP_2018.pdf

24. National Renewable Energy Laboratory (2014). Status and trends in the U.S. voluntary green power market. Retrieved from http://www.nrel.gov/ docs/fy16osti/65252.pdf

25. National Conference of State Legislators. (2019). State Renewable Portfolio Standards and Goals. Retrieved from http://www.ncsl.org/research/energy/ renewable-portfolio-standards.aspx

26. Nilsson, M., \& Sundqvist, T. (2007). Using the market at a cost: How the introduction of green certificates in Sweden led to market inefficiencies. Utility Policy, 15(1), 49-59. https://doi. org/10.1016/j.jup.2006.05.002

27. Papież, M., Śmiech, S., \& Frodyma, K. (2018). Determinants of renewable energy development in the EU countries. A 20-year perspective. Renewable and Sustainable Energy Reviews, 91, 918-934. https://doi.org/10.1016/j. rser.2018.04.075 
28. REN21. (2017). Renewables. Global Status Report. Retrieved from https:// www.ren21.net/wp-content/uploads/2019/05/GSR2017_Full-Report_ English.pdf

29. Schaeffer, G., Boots, M., Martens, J., \& Voogt, M. (1999). Tradable green certificates: a new market-based incentive scheme for renewable energy. Retrieved from https://books.google.com.ua/ books/about/Tradable_Green_Certificates.html?id=WjIdHAAACAAJ\&redir_ esc $=y$

30. Sineviciene, L., Kubatko, O., Derykolenko, O., \& Kubatko, O. (2018). The impact of economic performance on environmental quality in developing countries. International Journal of Environmental Technology and Management, 21(5-6), 222-237. https://doi. org/10.1504/IJETM.2018.10022295

31. Sotnyk, I. (2016). Energy efficiency of Ukrainian economy: problems and prospects of achievement with the help of ESCOs. Actual Problems of Economics, 1, 192-199. Retrieved from https://essuir.sumdu.edu.ua/ handle/123456789/43448

32. Sovacool, B., Sidortsov, R., \& Jones, B. (2014). Energy security, equality, and justice (240 p.). Routledge. https://doi. org/10.4324/9780203066348

33. State Statistics Service of Ukraine. (2019). Energy balance of Ukraine for 2018. Retrieved from http://www. ukrstat.gov.ua

34. The Verkhovna Rada Ukraine. (1997). Law of Ukraine "On Electric Power Industry”, No. 575/97-BP. Retrieved from https://zakon2.rada.gov.ua/laws/ show/575/97-\%D0\%B2\%D1\%80

35. Ukraine Sustainable Energy Lending Facility. (2014). Програма фінансування альтернативно енергетики України (USELF): посібник для девелоперів [Prohrama finansuvannia alternatyvnoi enerhetyky Ukrainy (USELF): posibnyk dlia developeriv]. Retrieved from http:// uabio.org/img/files/news/pdf/uself-redevelopers-manual-ua.pdf

36. Ukrainian Wind Energy Association. (2016). Technical and economic characteristics of wind power plant with a total installed capacity of $1 \mathrm{MW}$ : information letter No. 34.

37. Visser, E., \& Held, A. (2014). Methodologies for estimating Levelised Cost of Electricity ( $L C O E)$. Retrieved from https://res-cooperation.eu/images/pdfreports/ECOFYS Fraunhofer Methodologies_for_estimating_LCoE_Final_report.pdf

38. Wholesale Market of Electricity in Ukraine (2019). Analysis of prices on the WEM from September 1, 2018 till February, 1, 2019. Retrieved from http://www.er.gov.ua/doc.php?c=5 